Departments. In addition, the Government Chemist has a statutory function as official analyst or referee in cases of disputed analyses under various Acts of Parliament. Responsibility for the Laboratory was transferred from H.M. Treasury to the Department of Scientific and Industrial Research in July 1959.

\section{Exchange Programme in Nuclear Science}

A BROCHURE, The Exchange Programme in Nuclear Science, issued by the International Atomic Energy Agency outlines the opportunities offered by the Agency for visiting professors and scientists, the courses organized and the research grants available (Pp. 36 . Vienna: International Atomic Energy Agency, 1962). Information is included on the sponsorship of visits of scientists to foreign centres, the use of the mobile radioisotope laboratories and the financial arrangements. Lists of visiting professors, research grants made and training courses already organized and of the activities of the two mobile radioisotope laboratories are appended.

\section{Glass Manufacturers' Federation Fellowship}

THE importance of fundamental research to the modern glass industry is underlined by the endow. ment of a new research fellowship in the University of Sheffield by the Glass Manufacturers' Federation. Contributions towards the five-year fellowship have been subscribed by thirty-four firms in, or connected with, the British glass industry. Companies supporting the fellowship range in size from those employing more than 10,000 people, to small tradition firms of 100 or so craftsmen. The British glass industry ranks as the third largest glass producer in the world, but is probably one of Britain's smallest industries to support a distinct technology. The British industry played a direct part in the foundation, in 1917, of the Department of Glass Technology in the University of Sheffield, the first University school to undertake the study of glass technology as a separate applied science. This intimate connexion between the University and the industry has been maintained since that date, and Sheffield is still the source of the many glass technologists needed to-day by the highly mechanized glass industry. A feature of the Department is a strong postgraduate school, and the value of fundamental research is fully recognized by the industry. Further information concerning this fellowship can be obtained from Mr. J. Small, education officer, Glass Manufacturers' Federation, 19 Portland Place, London, W.1.

\section{World Inventory of Historic Scientific Apparatus}

A MeEting of the Commission de l'Inventaire Mondial des Appareils Scientifiques Historiques (president, A. Léveillé) was held in the United. Nations Educational, Scientific and Cultural Organization Building, Paris, on January 24, and was attended by representatives of scientific organizations in Austria, Belgium, Czechoslovakia, France, Germany, Holland, Israel, Italy, Luxembourg, Poland, the United Kingdom, the United States and the U.S.S.R. The Commission is supported by the United Nations Educational, Scientific and Cultural Organization, and has also received financial aid from many Governments and national institutions. Research into the use and whereabouts of historic scientific apparatus is now being carried out in twenty-eight countries, and national inventories are being made. A working group has been set up to examine possible methods for the presentation of the results. At the next meeting of the Commission, to be held on October 1 , the contributions from the various countries will be discussed with the view of incorporating the most important into a world inventory of historic scientific apparatus. Further information can be obtained from the Inventaire Mondial des Appareils Scientifiques Historiques, Palais de la Découverte, avenue Franklin D. Roosevelt, Paris 8e.

\section{The Field Studies Council}

THE annual report of the Field Studies Council, 1960-61 (Pp. 29. London: Field Studies Council, 9 Devereux Court, W.C.2, 1962), presented at the annual general meeting of the Council on February 16, includes the report of the Executive Committee and the reports of wardens at the field stations of Dale Fort, Flatford Mill, Juniper Hall, Melham Tarn, Preston Montford, Slapton Ley and Skokholm Bird Observatory. The steady progress of the previous 10 years was maintained and bookings increased again to 9,334 , from 8,539 in 1960 . Of these 5,183 were in biological and 3,006 in geographical and geological subjects. More than 2,000 applications had to be refused, and the executive committee is concerned at the number of last-minute cancellations and some failures to turn up for the courses booked. Of the individual attendances, 5,781 were from sixth forms, 782 from training colleges, 1,134 from universities and 1,249 amateurs. The membership is now approximately 4,000, comprising 1,050 corporate members and 2,950 individual members. Purchase of Dale Fort was completed in 1961, and in discussions with the Ministry of Education it has been agreed that the Ministry's grant should in future be for capital purposes and that the standard weekly fee should be raised by $10 s$. to $£ 810 s$. It is hoped that the settlement will permit an adequate programme of capital improvements at the centres and that this will include a scheme for converting the High Stables at Melham Tarn. The opening of an additional centre is under consideration and during the year about $£ 4,000$ was spent on improvements to buildings and equipment.

\section{British Technology Index}

IN British Technology Index the Library Association has issued a valuable current subject guide to articles in British technical journals. The term 'technical' is interpreted generously, the 402 periodicals covered in the first issue (January 1962) including a number which ostensibly are scientific rather than technical (1, No. 1; January 1962. A Current Subject Guide to Articles in British Technical Journals. Pp. 70. Published monthly. London: The Library Association. Annual subscription for 11 monthly issues and bound annual volume, $£ 1515 s$. post free; 50 dollars, U.S.A.). Delays through the postal dispute excluded a further 120 periodicals which it was intended to cover in this issue. Entries are arranged alphabetically by subject, with adequate and common-sense crossreferences, and are limited to title and bibliographical details. Among the features that should commend the Index to the industrial and technological user is the marked reduction in time-lag between publication. of an article and its inclusion in the Index. In this connexion it is worth directing attention to the effective reply of Mr. L. L. Ardern in the Library Association Record for February to some questions asked about the response to the Index from industrial libraries in the United Kingdom. 